1995 Ellipsis redundancy and reduction redundancy. Paper presented at Prague Workshop on Context, Prague.

Schwarzschild, Roger

1999 GIVENness, AvoidF and other constraints on the placement of accent. Natural Language Semantics 7: 141-177.

von Stechow, Arnim

1990 Focusing and backgrounding operators. In Discourse Particles, Werner Abraham (ed.), 37-84. Amsterdam: John Benjamins.

1991 Current issues in the theory of focus. In Arnim von Stechow, and Dieter Wunderlich (eds.), 804-835.

1996 Against LF pied-piping. Natural Language Semantics 4: 57-110.

von Stechow, Arnim, and Dieter Wunderlich (eds.)

1991 Semantics: An International Handbook of Contemporary Research. Berlin: Walter de Gruyter.

\section{Focus as identification}

\section{István Kenesei}

\section{Abstract}

Recent attempts to define the functions and domains of focus make a distinction between information focus on the one hand and identificational or contrastive focus on the other. While both types of focus are claimed here to be identificational, they differ in that information focus incorporates a weaker relationship between the set of individuals identified and the relevant set of elements in the discourse available to both speaker and hearer. In a reexamination of focus domains in Hungarian, a focus-sensitive language, it is shown that they have been taken to be too restrictive and too broad at the same time: a number of syntactic constituents previously disqualified can be interpreted as focussed provided both syntactic and prosodic factors are taken into consideration, while others prove to be focussable only as parts of larger syntactic and semantic units.

\section{Introduction ${ }^{1}$}

This paper is an attempt to redefine the functions and the semantic domains of focussing. Our central thesis is that focus has an identificatory function; and focus is understood here to comprise both information focus and identificational or contrastive focus. (We will try to clarify terminology, or at least list various terms and their usages, as we go along.) As far as the functions of focus are concerned, it will be shown that they differ in terms of the sets they refer to: information focus involves a subset relation, while contrastive focus makes use of a proper subset relation. Moreover, whether or not the contrasting complementary set is explicit, in case of contrastive focus a complementary set is always created. Once we define (some types of) focus, it is necessary to attend to the problems of where focus is manifested, i.e. what grammatical constructions can serve as the loci of focus. In this section we will 
show that earlier proposals err in limiting the domains of focussing to a fraction of the area actually concerned.

It is a corollary of the central thesis that identification can subsist only between items of a certain kind: those which have extensions in the world, i.e. things, actions, properties and propositions. Corresponding to this 'Fregean universe' are linguistic expressions such as referential noun phrases or DPs, predicates or VPs, and clauses or CPs/IPs. In terms of the proposals put forward here these exhaust the set of focussable categories in language. As a consequence of the nature of the questions, our investigation does not concern the syntax of focussing; it makes use of syntactic phenomena only insofar as they provide a diagnostics for the semantic properties and domains in question, and it makes reference to syntactic constituents only because they are the formal or categorial representations of such domains, although new data relevant to the syntax of focus will also be included.

First, various definitions of focus will be briefly surveyed. We will then argue that identification characterizes both information and contrastive focus, and point out the difference between the two. Next we will define the list of focussable categories, excluding from them adverbial adjuncts and attributes, and show in what ways adverbial adjuncts and attributes are similar to each other.

Focus arises through an intricate interaction of prosody (stress and/or pitch), syntax (at least in some languages), semantics and pragmatics. While it is not very easy to put one's finger on some specific type of focus in a number of languages, there are languages in which at least some subtypes of focus are grammaticalized, and just as it is easier to discuss gender by means of examples from languages where the distinction is manifest, so is focus more conveniently illustrated and ultimately accounted for if one can draw on examples that manifest it clearly. It is for this reason that examples from Hungarian, a language known for its overt syntactic and prosodic focussing processes, will be extensively used. As will be clear from the discussions that follow, even in a focus movement language such as Hungarian, prosody has an important role in determining the constituents in (semantic) focus. Nonetheless, no attempt will be made to determine the prosody-focus relation along the lines of, e.g., Gussenhoven (1984) or Zubizarreta (1998), partly because it would lead us too far afield, and partly because, at least as far as Hungarian is concerned, it is still possible to adhere to our proposals in Vogel and Kenesei $(1987,1990)$ and Kenesei and Vogel (1998).

\section{The varieties of focus}

While focussing seems to be well-defined when one considers a particular language, it becomes more elusive when examined over a range of several languages: prosodic highlighting may serve various, sometimes overlapping purposes. If focussing forms a continuum from different kinds of contrast to mere affective emphasis, then, depending on what is considered to be 'focus', we may end up selecting different regions from the area of prosodic highlighting. Since limitations of space prevent us from surveying various definitions of focus, ranging from Bolinger's (1961) emotional highlighting to Höhle's (1988) verum focus, Selkirk's (1984) narrow and broad focus, Gundel's (1999) psychological focus, Szabolcsi's (1981b) contrastive topic, or Hetzron's (1975) presentative focus, we will here concentrate on the two types that will be relevant to our discussion.

\subsection{Information focus}

Jackendoff (1972) calls information focus the information in the sentence that is assumed by the speaker not to be shared by him/her and the hearer. Note that this is practically the same definition as Rochemont's (1986) for presentational focus. Guéron (1980) observes that prosodic focus on the object NP in English results in either contrastive or noncontrastive interpretation, while prosodic focus on the subject NP is compatible only with contrastive focus.

Roberts (1998), following Rooth (1985), defines information focus as a constituent in an utterance whose value is permitted to vary in determining the Focus Alternative Set for the utterance, i.e., its denotation. She gives the formulas in (2) for the question-answer pairs in (1). (The '\#' sign stands for 'infelicitous' turns. Nuclear stress is marked by bold type throughout, except when to ensure unequivocal notation it is marked by double primes.)
(1) a. Who did Mary invite?
b. Mary invited Archibald.
c. \#Mary invited Archibald. 
(2) a. Q-alt(? Who did Mary invite $)=\{$ m invited $\mathrm{u}: \mathrm{u} \in \mathrm{D}\}$

b. $\|$ Mary invited $[\text { Archibald }]_{\mathrm{F}} \|=\{\mathrm{m}$ invited $\mathrm{u}: \mathrm{u} \in \mathrm{D}\}$

c. \#\|Mary ${ }_{\mathrm{F}}$ invited Archibald $\|=\{\mathrm{u}$ invited $\mathrm{a}: \mathrm{u} \in \mathrm{D}\}$

É. Kiss (1998) defines information focus as new, non-presupposed information marked by one or more pitch accents without expressing exhaustive identification in relation to a set of contextually or situationally given entities. (Glosses and translations here and throughout are É. Kiss's.)

(3) a. Hol jártál a nyáron?

where went-you the summer

'Where did you go in the summer?'

b. Jártam Olaszországban.

went-I Italy-to

'I went to Italy [among other places].'

(4) Mari ki nézett magának egy kalapot.

Mary out picked herself-DAT a hat-ACC

'Mary picked for herself a hat.'

\subsection{Contrastive focus, operator focus, identificational focus}

In Selkirk's (1984) prosodically based analysis contrastive focus must exhibit explicit contrast and is understood only as narrow focus.

\section{(5) She didn't watch " $M * A * S * H$ ", she watched "Kojak".}

Roberts (1998) defines contrastive focus with respect to information focus: contrastive focus differs from information focus in that it is marked for exhaustiveness modulo representations such as (2).

É. Kiss (1998) calls contrastive focus identificational focus and gives this definition: identificational focus "represents a subset of the set of contextually or situationally given elements for which the predicate phrase can potentially hold; it is identified as the exhaustive subset of this set for which the predicate phrase actually holds" (É. Kiss 1998: 249). She distinguishes identificational focus from contrastive focus, which operates on a closed set of entities whose members are known to the participants of the discourse; the identification of a subset of a given set also identifies the contrasting complementary subset. An identificational focus can be [ \pm exhaustive] and [ \pm contrastive], as in the following examples.

(6)

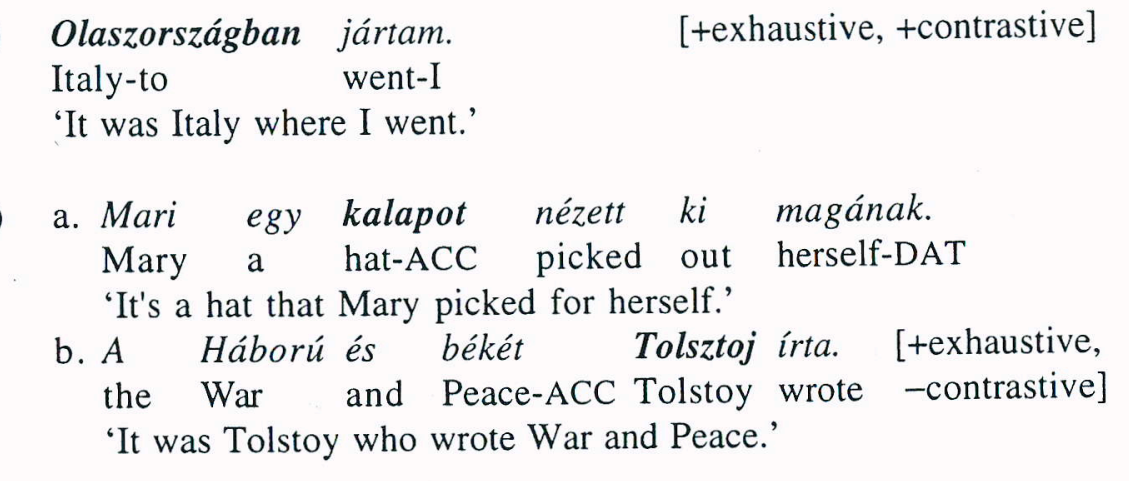

According to É. Kiss, there is a nonexhaustive but contrastive focus in Finnish, which she calls 'contrastive topic', as in the following example. For an alternative view of contrast in Finnish, see Molnár and Järventausta (2003).

(8) a. Where do Anna, Kati and Mikko live?
b. [Anna] asuu täällä. [-exhaustive, +contrastive]
Anna lives here
'Anna, she lives here.'

The interpretation is one of contrastive topic, with \{Anna, Kati, Mikko\} in a superset, of which only Anna is identified and thus contrasted with the other members of that set.

\section{Focus defined as identification}

\subsection{Lists, sets, exhaustivity}

The first to discuss the semantics of focus in a generative framework was Chomsky (1971), who in effect divided the sentences into focus and 
presupposition, and attributed to them the semantics of an identity statement, cf. (9).
(9) a. John writes poetry in his study.
b. It is in his study that John writes poetry.
c. The place where John writes poetry is his study.

Chomsky's problem at the time was how surface structure, and, in particular, (contrastively) focussed constituents, can determine or modify semantic interpretation, and it was along these lines that Jackendoff (1972) elaborated some of Chomsky's initiatives, before Chomsky (1976) himself again took up this and related issues.

Szabolcsi (1981a, 1981b) challenged the received view of focus/presupposition division by claiming that exhaustive listing was the predominant characteristic of focus, at least in the Hungarian examples she used. In her analysis sentence (10a) was assigned the reading in (10b).

\section{(10) a. Péter aludt a padlón.

Peter slept the floor-on \\ 'It was Peter that slept on the floor.'}

b. 'For every $\mathrm{x}, \mathrm{x}$ slept on the floor if and only if $\mathrm{x}$ is Peter.'

Kenesei $(1984,1986)$ offered a re-analysis of Szabolcsi's data arguing that it is erroneous since the stress patterns of the clauses differ depending on what is focussed in the contrasting clauses, and suggests that the function of focus is 'exclusion by identification' interpreted on some set of individuals in the universe of discourse. By selecting one element of the set, all other members are excluded. Thus, the sentence in (10a), now understood as having focus only on the subject noun phrase, would correspond to the interpretation in (11a), which returns to Chomsky's $(1971,1976)$ original formula, and can be generalized for similar types of foci in (11b) as paraphrased in (11c).

(11) a. 'The one that slept on the floor is Peter.'

b. $\iota x(F x)=a, x \in \mathrm{R}$ (where $\mathrm{R}$ is the relevant set in the universe of discourse)

c. the $x$, such that $x \in \mathrm{R}$, for which $\mathrm{F}(x)$ is the case, is identical with $a$
Szabolcsi (1994) accepted this interpretation for reasons related to the difference of focus and quantifier interpretation, which she elaborated in Szabolcsi (1997).

Katalin É. Kiss's $(1998,2002)$ recent contribution to the analysis of the semantics of focus is the definition quoted above in 2.2 and is put to use in examples such as those below, in which, of the relevant set of entities, it is always egy angol könyv 'one English book' that John got as a present, and the sentences differ in the sets of entities from which one English book is selected.

(12). a. János [egy angol könyvet $]$ kapott ajándékba. John one English book-ACC got as-present 'It was one English book that John got as a present.'

b. János [egy angol könyvet] kapott ajándékba. 'It was one English book that John got as a present.'

c. János [egy angol könyvet] kapott ajándékba. 'It was one English book that John got as a present.'

d. János [egy angol könyvet] kapott ajándékba. 'It was one English book that John got as a present.'

The relevant sets of which the object denoted by egy angol könyv 'one English book' is a subset differ in the following ways. In the case of (12a) it is the set English books of various cardinality, in (12b) the set of books in various languages, in (12c) the set of English objects, and finally in (12d) it is a set of objects believed by the speaker to be known to the hearer. In other words, unlike others, including Rooth (1985), É. Kiss regards the bracketed items as focussed, rather than the boldface ones (É. Kiss 1998: 260).

Although she proceeds to make the claim that identificational focus has to be constrained to exclude that-clauses, infinitival clauses, VPs, as well as predicative NPs and APs (É. Kiss 1998: 261) - a claim which we will show to be in error -, we can none the less base our analysis of focussing on this proposal. We will begin by examining the relationship of information focus to identificational focus. 


\subsection{Information focus: A new proposal}

Information focus is characterized as 'new information' (for the hearer) and we believe this position to be fully justified. However, assigning the label 'new' to any constituent in a sentence contributes little to the interpretation of the sentence in the logico-semantic analyses customary in the approaches reviewed here. One of the objectives this paper has is to integrate information focus in precisely those approaches.

Although there is no general procedure to determine information focus, most researchers make use of answers to question-word (or wh-) questions to decide the constituents involved, and it is this method that we will apply here. To begin with, let us recall Roberts' (1998) and É. Kiss's (1998) examples.
(13) a. Kit
hivtál meg?
who-ACC invited-you
'Who did you invite?'
b. Meg-hívtam például Jánost.
PV-invited-I for-example John-ACC
'I invited John, for example.'
(14) a. Hol jártál a nyáron?
where went-you the summer-on
'Where did you go in the summer?'
b. Jártam Olaszországban.
went-I Italy-to
'I went to Italy [among other places].'

If questions are requests for identifying the value of the variable in them along the lines of Chomsky (1977), then the two questions above can be rendered in the following manner.

(15) a. For which $x, x$ a person, you invited $x$

b. For which $x, x$ a country, you went to $x$ in the summer

The restrictor, which gives the set of which the variable is a member was no doubt determined here rather loosely. In (15a), for instance, the set of persons is probably more limited, including only persons relevant (in some sense) to both speaker and hearer. As for (15b), the question-word where does not necessarily imply names of countries. Even so, we may conclude that the type of question to which an answer with an information focus corresponds is asking for identification.

Consequently, the answer given to such questions must also contain some form of identification; however, this operation is not the type of identification that excludes (all) other members of the relevant set, but one that allows for the predicate to hold for other possible elements of the set. In other words, if other members of the relevant set happen truthfully to give the value of the variable in the question, the answer is still not false, ill-formed, or inappropriate. The crucial section of the formula that corresponds to such statements contains the 'member-of' relation, and the answers in (13b) and (14b) can be interpreted roughly as below.

(16) a. John $\in A$, where A: person(s) I invited

b. Italy $\in$ B, where B: countri(es) I went to in the summer

What must be added to this interpretation is that it makes no claim with regard to the membership of the sets which include, respectively, John and Italy; they may contain no additional elements, or they may contain an indefinitely large number of elements, but they must contain at least one element each. Notice further that the questions are not (or not necessarily) inquiries as to exhaustive answers, and probably that is why 'partial' answers, such as those in (13b) and (14b) are considered satisfactory.

But the formula for an answer as given in (16) suffers from a deficiency: it does not strictly correspond to the identification requested in the respective questions; all it does is assert the membership of some individual in a set. We suggest therefore that information focus be rendered rather by the following informal representations, in which one of the propositions constitutes an identity statement.

(17) a. $\exists x$, such that $x \in$ \{persons I invited \}, and $x$ is John

b. $\exists x$, such that $x \in$ \{countries I went to in the summer , and $x$ is Italy

At this point we may conclude that both information focus and identificational (or contrastive) focus involve an existential proposition and a statement of identification and they differ in that the latter makes use of 
the iota operator, whose function in Russell's (1905) sense is to ensure the unicity of the extension of the individual variable in its scope. We will return to further differences in the next section.

Before we do so, let us call attention to the fact that even the empty set can be given as the extension asked for in $(13 a) /(14 a)$, that is, a negative answer is quite possible, although it contradicts the ostensible presupposition in the question. If the identification of the value of the variable is impossible or is denied, the answers may take the following forms.

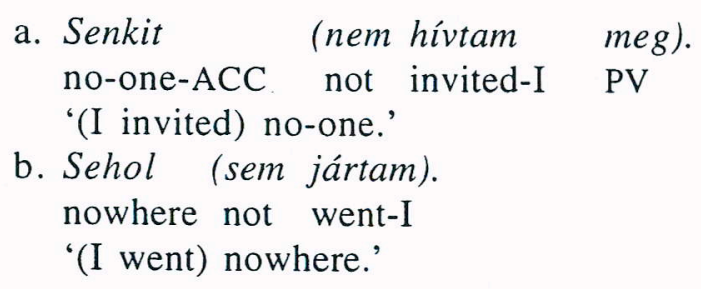

The answers in (18) are equivalent to asserting that the extensions of the sets of persons or countries are null. This is a possible and appropriate type of answer to many, though not all, kinds of wh-questions. In this case, the corresponding question is meant to be interpreted by the speaker, or can be reinterpreted by the hearer, as 'for which $x$, if any, does $\mathrm{F}(x)$ hold true?' or 'is there an $x$ such that $\mathrm{F}(x)$, and if so, what is the value of $x$ ?', and there would be no problem in having to cancel in the answer the putative presupposition, which turns out to be one of the conjuncts in the question. In fact, the existential quantifier in the formula in (17) points at the nature of the corresponding question: information focus questions can ask for an existential assertion, as it were, whereas contrastive focus questions contain the existential assertion as their presupposition.

\subsection{Information focus versus identificational/contrastive focus}

If the analysis above is plausible, then information focus will correspond to the general formula in (19a), while identificational (or contrastive) focus to the one in $(19 b)$.
(19) a. $\exists x$, such that $x \in A$, and $x$ is John; A contains at least one individual

b. the $x$, such that $x \in \mathrm{A}^{\prime}$, is John; $\mathrm{A}^{\prime}$ contains exactly one individual

where the sets $\mathrm{A}$ and $\mathrm{A}^{\prime}$ are those of the person(s) I invited, and both are subsets of the relevant set of discourse R. In other words, for information focus what is asserted is that there is an individual that I invited and that this individual is John, the fact that I invited someone being the presupposition, and it may very well be the case that John is the only person I invited or, equally, that there were additional persons that I invited. By means of information focus the speaker makes no commitment as to the further membership of the set that John is a member of.

On the other hand, identificational/contrastive focus must make the explicit commitment that the set of persons I invited contains no individual in addition to John, or in general, those listed in the focussed expression. But although this difference derives from (19), one important aspect is left unaccounted for: identificational/contrastive focus implies that there is at least one individual other than John for whom the proposition does not hold. Thus, we ought to complement the formula in (19b) in the following way.

(20) the $x$, such that $x \in \mathrm{R},(\mathrm{F} x)=a$, where $\mathrm{R}$ is the relevant set in the universe of discourse, and $a \in \mathrm{R}$, and $\exists b$, such that $b \in \mathrm{R}$, and $b \neq$ a.

All in all, both types of focus are instantiations of identification and the difference between them boils down to the nature of the set-theoretical relations they determine. Information focus incorporates a subset relation between the individual(s) identified and the set that the individual(s) in question is/are contained in, while identificational (or contrastive) focus relies on a proper subset relation. In a subset relation, $\{x\} \subseteq \mathrm{A} \subseteq \mathrm{R}$, $\{x\}$ is contained in A, and A may or may not have an element outside the set of $\{x\}$, with A being a subset of the relevant set of discourse $\mathrm{R}$. In a proper subset relation, $\{x\} \subset \mathrm{R},\{x\}$ is contained in $\mathrm{R}$, the relevant set of discourse, but $\mathrm{R}$ must have at least one element not in $\{x\}$. But if both types of focus incorporate identification, then labelling only one of them 'identificational' is misleading. Therefore, we will return to the term 'contrastive focus'. 
It is not only answers, but also questions that may vary as to whether they inquire about information or contrastive focus. If I am aware that Jim goes shopping occasionally and ask the question in (21a), the answer could be either (21b) or (21c). But if I saw Jim buy something yesterday in some clothes store (and he knows that I did) and then ask the question in (21a), the answer in (21c) would be out of place.

(21) a. What did you buy yesterday?

b. (I bought) a hat.

c. (I bought) nothing.

In the first scenario we have to do with an information focus question, in the second, a contrastive focus question. Moreover, the sentence in (21b) is also ambiguous between the two types of focus but only in answer to the information focus question. In other words, when I ask Jim what he bought, if he bought anything at all, he may choose to give me a partial answer specifying one of the things he bought, making no commitment as to reporting to me all the things he bought that day. If, however, I know that Jim bought something (and Jim is aware of this), an answer incorporating a mere information focus would be unsatisfactory. Then there is no doubt as to the fact that he bought something, i.e., the presupposition cannot be cancelled, and the merchandise that changed hands in the transaction in question has to be fully identified, as it were, and set against all other items that may have been involved in that transaction. This is essentially the same equivocation as was noted in Guéron (1980) and by many others since.

The case is somewhat less ambiguous in Hungarian. Although the two interpretations of the question do not in general show up in this language either, 'positive' answers may differ in their syntax (unless they are 'short' replies).
a. Mit vettél tegnap?
what-ACC bought-you yesterday 'What did you buy yesterday?'
b. (Vettem) egy kalapot.
bought-I a hat-ACC
'I bought a hat.' (I-focus)
c. Egy kalapot (vettem).
'It was a hat that I bought.' (C-focus)

The sentence final position of the object DP indicates that it is information (I) focus, while the preverbal position signals contrastive (C) focus.

In summary, we are on the whole in agreement with É. Kiss (1998) in determining the function and interpretation of her identificational (our contrastive) focus, repeated here for convenience.

(23) a. Identificational focus represents a subset of the set of contextually or situationally given elements for which the predicate phrase can potentially hold; it is identified as the exhaustive subset of this set for which the predicate phrase actually holds.

(É. Kiss 1998: 245)

b. Contrastive focus operates on a closed set of entities whose members are known to the participants of the discourse; the identification of a subset of a given set also identifies the contrasting complementary subset.

(É. Kiss 1998: 267)

Where we differ is in our claim for a proper subset relation instead of her subset relation, ${ }^{2}$ and on the issue of the nature of information focus, which we understand as carrying out the same kind of identification as her identificational focus; the latter, however, misses the proper subset relation to the entities invoked or implied by the former type.

We can now follow two tracks here. The more conciliatory solution is to by and large accept É. Kiss's (1998) generalizations and modify them only to the extent of claiming that they both rely on identification and information focus as [-exhaustive], while conceding that identificational/contrastive focus is [+exhaustive, \pm contrastive].

If we took the more contentious position, we could challenge the distinction between her identificational and contrastive focus and claim that they are one and the same, at least for Hungarian, especially because her arguments for the [-contrastive] feature are particularly weak. She claims that focus is [ \pm contrastive] in examples like ( $7 \mathrm{~b})$ because "the identification of the subset for which the predicate holds does not result in the delineation of a complementary subset with clearly identifiable elements" (É. Kiss 1998: 268). ${ }^{3}$

But is "a complementary subset with clearly identifiable elements" a necessary precondition for contrastive focus? Or is it possible that there are complement sets whose membership may differ between speaker and hearer, but as long as there are elements in these sets in addition to the one represented by the subset in focus they can qualify for contrastive 
focushood? Clearly a question such as Who wrote War and Peace? must be interpreted with respect to a set of persons who may have written the novel, just as in the following dialog the set of people who may have broken the window is indefinitely large, but once the answer is given any other member of a real complementary subset is excluded. Thus contrastive focus always creates complementary subsets with real, though often undetermined membership.

(24) a. Who broke the window?

b. Jim Jones did (break the window).

(25) a. Ki törte be az ablakot? who broke PV the window-ACC

b. Kovács János (törte be az ablakot).

'John Smith (broke the window).'

c. *Kovács János (be-törte az ablakot).

approx. 'Among others John Smith broke the window.'

Note that $(25 \mathrm{c})$ is ungrammatical because no answer giving an information focus is possible. The question cannot be answered by specifying an information focus because all and only the persons who broke the window must be given. Consequently, everyone else, i.e., all members of the complement set, whether or not it is understood by the speaker and the hearer to have the same extension, are excluded.

If É. Kiss were right, the focus position could be filled in by exhaustively, though not contrastively focussed items, such as a nap "the sun' in the following example.

\section{a. *[A nap $]$ sütött ki a felhók mögüll. the sun shone out the clouds from-behind} approx. 'It's the sun that's shining through the clouds.'

b. A nap ki-sütött a felhök mögül.

approx. 'The sun is shining through the clouds.'

Since the predicate süt 'shine; burn' is applicable in this context only to the sun in Hungarian, and thus nothing but the sun can shine through the clouds (in the original), exhaustive focus should be possible. ${ }^{4}$ But it is an option only in English, not in Hungarian, where the focus position has to be [+contrastive]. Note finally that if the focus position carries the property of exhaustiveness, it would be a mystery why universal quantifiers cannot be focussed, although the feature [+exhaustive] applies perfectly well to them.

(27) a. Mindenki meg-vett egy kalapot. everyone PV-bought a hat-ACC

'Everyone bought a hat.'

b. *Mindenki vett meg egy kalapot.

c. *It's everyone that bought a hat.

If, however, focus carries the property of contrastivity, universal quantifiers will be naturally barred from this position, because they cannot be interpreted as a proper subset of any relevant set that contains a complementary subset.

\section{The domains of focussing}

We contend that É. Kiss's $(1998,2002)$ delimitation of constituents in focus, cited at the end of 3.1, is too restricted: VPs and clauses can also be focussed in Hungarian (and arguably in English, too). In this section we will show that some grammatical categories are 'more focussable' than others, and in the last section we will speculate as to a possible 'focus ontology' behind this state of affairs.

\section{1. (Un)focussable categories}

While there is general agreement in the fact that DPs are perfectly capable of occurring as foci, other categories are often claimed to fall outside the domain of focusability, as was seen in É. Kiss (1998). The examples to support her case are as follows. (Focussed constituents are bracketed and some of the glosses changed.)

(28) a. *János [(azt) hogy Mari elkésik]

John it-ACC that Mari is-late

súgta nekem

tensed $\mathrm{CP}$

whispered me

*'It was that Mary would be late that John whispered to me.' 




However, É. Kiss makes the mistake of taking the syntactic focus position as the (criterion of) semantic focusability by maintaining that the examples in (28) are unacceptable because the expressions in focus do not denote individuals. While the bracketed phrases indeed cannot be placed in the preverbal focus position, neither É. Kiss's list of nonfocussable categories, nor the examples in (28) can be maintained in the face of data to the contrary.

First of all, that-clauses can be focussed in Hungarian on condition that it is not the clause that is moved into the designated focus position but the expletive $a z$ 'it', which is assigned the appropriate case, while the clause carries the thematic role discharged by the verb or adjective of which it is the complement, as was shown in Kenesei (1994).

\section{(29) János (nem) azt súgta nekem [hogy Mari elkésik] John not it-ACC whispered me that $M$. is-late 'What John whispered to me was (not) that Mary would be late.'}

Note that clauses can be 'represented' by the expletive also in the Topic position and in the so-called is 'also' construction, usually placed between the Topic and the Focus positions in the sentence. Observe also that the grammar of Hungarian is quite uniform in excluding all tensed complement and adjunct (relative) clauses from the preverbal focus position, as also shown in Kenesei (1994).

As far as VPs are concerned, Kenesei (1998) made a case for VP focus in Hungarian demonstrating that it is realized in two varieties: (a) the main verb carries primary stress with all major constituents lined up following it and receiving primary stresses; and (b) one of the referential arguments or adjuncts is placed in focus position with the verb destressed and all other major constituents stressed behind the verb. Note that the case for VP focus was also used at the time to argue for the existence of the category of VP in a subject-predicate division in Hungarian, in contrast with the proposal that Hungarian has a 'flat' sentence structure, as claimed in É. Kiss $(1987,2002)$. The (a) version is illustrated in $(30 \mathrm{a})$, the (b) version in $(30 \mathrm{~b}-\mathrm{c})$. The focussed VP is indicated by bracketing.

\section{(30) a. Péter [fel-olvasta a Hamletet a kertben] Peter PV-read the Hamlet-ACC the garden-in (nem pedig szott). not rather swam \\ b. Péter [a Hamletet olvasta fel a kertben] (nem pedig úszott). \\ c. Péter [a kertben olvasta fel a Hamletet] (nem pedig úszott). 'What Peter did was read out Hamlet in the garden (rather than swim).'}

As is seen from the examples, entire VPs can be negated in focus: in contrast with clausal or 'unmarked' sentential negation when the preverb-verb order is reversed, their order is (or 'remains') preverb-verb in the case of focussed VP-negation. In the other variety of focussed VPnegation one referential DP is placed in the focus position following the negative word.
(31) a. Péter
Peter not PV-read
(hanem úszott).
$a$
but swam
b. Péter nem [a Hamletet olvasta fel a kertben] (hanem úszott).
c. Péter nem [a kertben olvasta fel a Hamletet] (hanem úszott).
'What Peter did was not read out Hamlet in the garden (but swim).'

Infinitival clauses can also be focussed, although they, too, are prohibited from moving into the syntactic focus position as clauses. The focussing of infinitives is carried out along much the same lines as the focussing of VPs at least in affirmative sentences: either (a) the infinitive, or (b) one of the other constituents is placed in the preverbal focus slot. 
In sentences containing negated infinitival focus, the carrier verb must be repeated in the contrast clause, as in $(32 \mathrm{c}, \mathrm{d})$.

a. János olvasni akarta a Hamletet
John to-read wanted the Hamlet-ACC
(nem pedig szaladgálni).
not rather run-around

b. János a Hamletet akarta olvasni (nem pedig szaladgálni).

'What Peter wanted to do was read Hamlet (rather than run around).'

c. János nem olvasni akarta a Hamletet

John not to-read wanted the Hamlet-ACC

(hanem szaladgálni *(akart)).

but run-around wanted

d. János nem a Hamletet akarta olvasni (hanem szaladgálni *(akart)).

'What Peter wanted to do was not read Hamlet (but run around).'

É. Kiss's original examples cannot be used for reasons unrelated to the problem at hand: minden évben 'every year' in (28b) is a universal quantifier, which must be moved into the matrix clause, thus preventing the rest of the clause from being focussed. The example in (28c), in turn, contains a preverb-verb combination, which elicits a pattern somewhat different from the above, since the 'carrier verb', which happens to be the auxiliary fog 'will' here, has to be repeated in the contrast clause in both affirmation and negation.

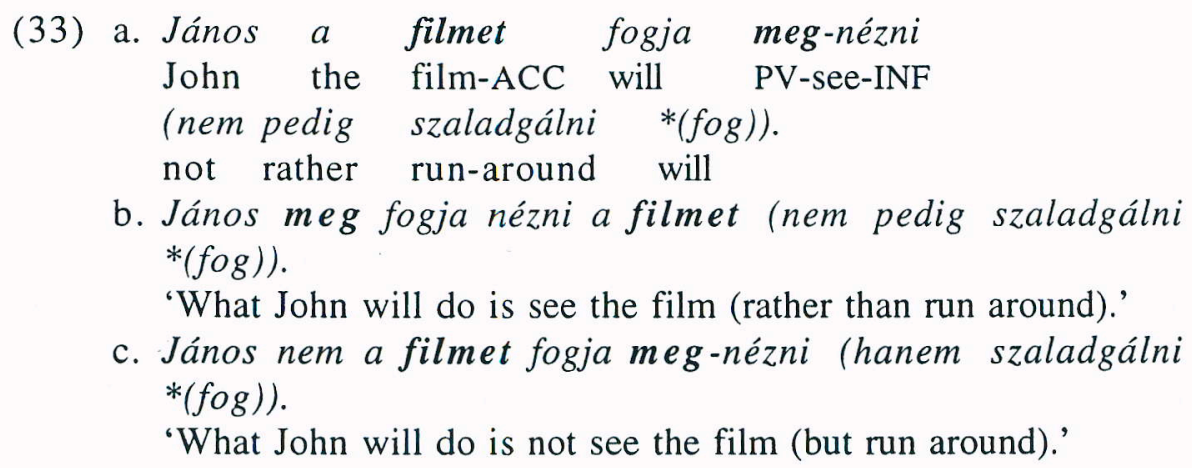

b. János meg fogja nézni a filmet (nem pedig szaladgálni $*(f \circ g))$.

'What John will do is see the film (rather than run around).'

c. János nem a filmet fogja meg-nézni (hanem szaladgálni $*($ fog $))$.

'What John will do is not see the film (but run around).'

Finally, we also disagree with É. Kiss as regards the alleged general nonfocusability of predicate nominals and adjectives: we argue that these are focussable just like other predicates, but of course not in the form of nouns or adjectives (or NPs, NumPs, APs, etc.), but as full predicates complete with the copula. In other words, when the following sentences are considered, it is not $(a)$ soldier versus $(a)$ cook, or tired versus upset that is contrasted, but be a soldier or being a soldier and be(ing) a cook, or be(ing) tired and be(ing) upset, as is illustrated by the options provided by the contrast clauses, which contain verbal predicates derived from the corresponding noun or adjective.

(34) a. Péter katona volt, nem pedig szakács
Peter soldier was not however cook
(volt)/szakácskodott.
was/worked-as-a-cook
'Peter was a soldier, not a cook.'
b. Anna nem fáradt volt, hanem
Anna not tired was but
(csak) ideges (volt)/idegeskedett
only upset (was)/acted-upset
'Anna was not tired, she was (only) (acting) upset.'

É. Kiss's example (28d) sounds unnatural for an independent reason: it contains the 'negative' adverbial ritkán 'seldom', whose canonical position is the preverbal focus slot, and whenever something other than his adverbial is focussed, it appears as an instance of 'quotative context', cf. Bolinger (1961).

\subsection{Sentential focus}

For quite some time the Hungarian preverbal focus position has been considered to provide indisputable evidence for interpreting only the item occupying it as contrastive focus. As was shown in the previous section in relation to VP-focus, cf. (30)-(32), the focus position also serves as a marker for the focussing of a constituent larger than what is actually placed there. There is another set of examples from the literature that illustrates this property. 
It was again É. Kiss (1998) who called attention to a structure in which the subject occupies the focus position and the whole sentence is understood as being in (information) focus.

(35) a. What's new?

b. [Focus Jelcin] nyerte meg az orosz választásokat.

'Yeltsin has won the Russian elections.'

Note that the following nonfocussed PV-verb order would also be possible and acceptable in answer to the question in (35a):

\section{(36) "Jelcin "meg-nyerte az "orosz "választásokat Yeltsin PV-won the Russian elections-ACC \\ 'Yeltsin has won the Russian elections.'}

In this sentence the subject DP Jelcin is not placed in the syntactic focus position, but is in Topic, and the sentence is in all respects identical with what has been termed 'neutral', i.e. nonfocussed, in the literature on Hungarian, with primary stresses as marked by the double primes.

The slight difference between the two answers in (35b) and (36) somewhat resembles that between the familiar examples from Schmerling (1976) cited below.

\section{(37) a. Johnson died.}

\section{b. Truman died.}

This pair of sentences has been interpreted as differing in that Truman's terminal illness had been in the news for some time before he passed away, while Johnson's death was something out of the blue. In other words, the difference in the ways these sentences are focussed is due to the difference in the speaker's beliefs as to the hearer's knowledge, producing presentational focus in (37a), as against a more restricted information focus in (37b).

The two Hungarian examples might differ again in terms of (speaker's beliefs of) hearer expectations: if the speaker presumes that the hearer is aware of the candidates in the elections, even though s/he may not know that the elections took place the day before, $(35 b)$ is a possible answer. If the speaker thinks that the hearer knows nothing about Yeltsin or the Russian elections, (35b) would be out of place, and (36) is a more probable reply. A similar regularity can be observed in the following:



For $(38 \mathrm{a}, \mathrm{b})$ to be a plausible answer, Imre Kertész must be a potential, though strictly speaking, unofficial, candidate for the Nobel Prize known to the hearer; no such precondition has to exist in case of (38c), assuming, of course, that the speaker believes that the hearer knows who Imre Kertész is. It is perhaps interesting to note here that to break the news of Kertész's Nobel Prize award, (38a,b) are more likely than (38c), owing to the ensuing preferred interpretation, which suggests that 'we have known all along that he was a potential laureate.'

In short, in addition to focussing embedded clauses, it is possible to place focus on matrix clauses.

\subsection{The nonexistent V-focus}

It is virtually unquestioned in the literature that verbs can be focussed just as any other constituent (cf. Brody 1990, É. Kiss 1992, 1994, Choe 1995, Ambar 1999, Bayer 1999). We will now challenge that view. In the following examples from Hungarian (cf. Brody 1990) and Portuguese (Ambar 1999), respectively, the verbs are claimed to carry contrastive focus.
(39) a. Nem utál-om
Jánost, hanem not hate-1SG-DEF.OB János-ACC but
'I don't hate John, I like him.'
szeret-em. like-1SG-DEF.OB




$\begin{array}{lll}\text { b. AMaria beijou o } & \text { Pedro. } \\ \text { Mary kissed } & \text { Peter } \\ \text { 'Mary kissed Peter.' } & \end{array}$

Although it is obvious that the verbs carry nuclear stress in these sentences, it is less evident that it is only the verbs that are (semantically) focussed. As far as Hungarian is concerned, this assumption follows from É. Kiss's controversial view that Hungarian sentences have a 'flat' structure without a VP, which Brody (1990) accepted and which allows no 'focus percolation' to any constituent above the verb but below the level of the clause. It is easy to show, however, that in case of a putative verb-contrast, more constituents than the verb itself must carry primary stress, showing a pattern similar to that in (12). In other words, some constituents are destressed because they (or rather, their denotations) are contained in the superset of which both contrasted actions form subsets.

(40) János nem "olvasta a könyvet, hanem a "legyeket
John not read the book-ACC but the flies-ACC
"csapkodta (vele).
slapped with-it
'John didn't read the book, he (actually) slapped flies with it.'

The relevant sets of which the denotations of the VPs in (40) are subsets are actions involving the book. Verbs, in general, do not exist 'in isolation', i.e., without their (internal) argument structure: there is no buying, liking, kissing or reading without buying, liking, kissing, or reading something or someone. Ellipsis or deaccenting is the result of a presupposition like that of the book but it is still part of the domain of focussing in the case of the examples in (12a-b). In other words, it is not the denotation of hate that is contrasted with that of like, but those of hating John and liking John in (39a), excluding this or all other members of the supersets formed of actions or states.

\subsection{Adjuncts in focus}

As is well-known, cleft focus in English can host at most one constituent. This observation has resulted in their being used, among others, for constituency tests, as shown in the following examples.
(41) a. It's the garden that he is showing to Maud.

b. *It's the garden to Maud that he is showing.

c. *It's Maud the garden that he is showing.

However, as was first noticed by Taglicht (1984), in certain cases more than one constituent can be focussed in a cleft sentence.

(42) a. It was three years ago (and) in London that I first met him.

b. It was rather infrequently (and) in Paris that we met after that.

Note that both items must be adjuncts, that is, it is not possible to place an argument along with an adjunct.

(43) *It was Maud (and) three years ago that I met.

Independently of Taglicht, É. Kiss (1994) recognized a similar regularity in focussing adjuncts in Hungarian. In applying Szabolcsi's (1981b) original test for exhaustive listing, she noted that an unlimited number of adverbials may simultaneously be true of one and the same action, or, equally, in case of conjoined adverbials in focus, one conjunct in focus is a possible consequence in contrast with argument DPs.
(44) a. Mari szépen vasalta ki az inget.
Mary beautifully ironed PV the shirt-ACC
'Mary ironed the shirt beautifully.'
b. Mari szépen és gyorsan vasalta $k i$ az inget.
Mary beautifully and quickly ironed PV the shirt-ACC
'Mary ironed the shirt beautifully and quickly.'

In other words, (44b) does not contradict (44a), and the truth of (44a) follows from the truth of $(44 b)$, unlike in the case of $(45 a, b)$, where $(45 b)$ contradicts (45a), and the truth of $(45 a)$ does not follow from the truth of (45b).
(45) a. Mari Pétert látogatta meg.
Mary Peter-ACC visited PV
'It was Peter that Mary visited.'
b. Mari Pétert és Annát látogatta meg.
Mary Peter-ACC and Anna-ACC visited PV
'It was Peter and Anna that Mary visited.'


For a piece of new evidence, consider the following dialogues. The dialogue in $(46 \mathrm{a}, \mathrm{b})$ is well-formed, since propositions containing conjoined DPs in focus are true even under conditions different from when one of their conjuncts is in focus, while the dialogue in $(46 \mathrm{a}, \mathrm{c})$ is ill-formed for the same reason.

(46)
a. Mari Pétert látogatta meg.
Mary Peter-ACC visited PV
'It was Peter that Mary visited.'

b. Nem, Mari Pétert és Annát látogatta meg.

No Mary Peter-ACC and Anna-ACC visited PV

'No, it was Peter and Anna that Mary visited.'

c. \#Igen, Mari Pétert és Annát látogatta meg.

Yes, Mary Peter-ACC and Anna-ACC visited PV

\#'Yes, it was Peter and Anna that Mary visited.'

In contrast, similar dialogues containing adjuncts in focus show a reversal in acceptability. That is to say, conjoined manner adverbials in focus do not contradict an assertion in which only one of the conjuncts is focussed.
a. Mari szépen vasalta $k i$ az inget.
Mary beautifully ironed PV the shirt-ACC
'Mary ironed the shirt beautifully.'

b. \#Nem, Mari szépen és gyorsan vasalta ki az inget.

No Mary beautifully and quickly ironed PV the shirt-ACC \#'No, Mary ironed the shirt beautifully and quickly.'

c. Igen, Mari szépen és gyorsan vasalta ki az inget.

Yes Mary beautifully and quickly ironed PV the shirt-ACC

'Yes, Mary ironed the shirt beautifully and quickly.'

When É. Kiss (1994) discussed the contrast between (44) and (45), she attributed their difference to the fact that these adverbials are nonreferential and focussable entities must be referential. She also noted that each adverbial in focus can also perform "identification with exclusion" in case of explicit contrast, as in answer to a question like Did Mary iron the shirt beautifully or carelessly? We might add to her observation that explicit contrast is not a prerequisite for the exclusion of adverbials of the same 'semantic dimension'. Once the predicate ironed the shirt quickly holds for some action, any other predicate incorporating an expression mentioning the speed of the action is out of place, i.e., excluded, but a predicate indicating some other circumstance, manner, etc., of the same action is perfectly compatible with it.

Observe that it is not simply adverbials but the predicates containing them that constitute reference sets for (contrastive) focus. And predicates, as was seen above, are perfectly focussable entities, although not referential in the sense É. Kiss seems to have used the term. However, this interpretation raises a new set of questions.

It was claimed in Kenesei (1998) that there is a contrast between referential and nonreferential adjuncts when focussed. The focus interpretation is projected onto the (internal) VP, i.e., the predicate, only if (a) the verb is initial in the VP, or (b) the syntactic focus position contains an argument, or (c) a referential adjunct, as was seen also in (30)-(32). (The scope of semantic focus is represented by small capitals, the syntactic focus position is bracketed, and primary stresses are marked by double primes.)
(48) a. "Péter "FEL-OLVASTA A "HAMLETET A Peter PV-read the Hamlet-ACC the "KERTBEN (nem pedig úszott). garden-in not rather swam
b. "Péter [A "HAMLETET] OLVASTA FEL A "KERTBEN (nem pedig úszott).
c. "Péter [A "KERTBEN] OLVASTA FEL A "HAMLETET (nem pedig úszott).
"What Peter did was read out Hamlet in the garden (rather than swim).'

If a nonreferential adjunct is in the syntactic focus position, the projection to VP-focus interpretation is not possible, see (49a). Here either focus interpretation is restricted to the nonreferential adjunct, cf. (49b), or if VP-focus is intended, the adjunct must not be placed in the focus position, but moved in front of it, as is indicated by the preverb-verb order in $(49 \mathrm{c})$.

$\begin{array}{llll}\text { (49) a. *"Péter ["HANGOSAN] } & \text { OLVASTA } & \text { FELA "HAMLETET } \\ & \begin{array}{l}\text { Peter aloud } \\ \text { (nem pedig úszott) }\end{array} & \text { read } & \text { PV the Hamlet-ACC } \\ \text { not rather swam } & & & \end{array}$


b. "Péter ["HANGOSAN] olvasta fel a Hamletet.

'Peter read Hamlet out aloud.'

c. "Péter "HANGOSAN "FEL OLVASTA A "HAMLETET (nem pedig úszott)

'What Peter did was read out Hamlet aloud (rather than swim).'

This is a scenario analogous to the one that was illustrated in connection with the focussing of DPs containing an attribute, cf. (12b). It is a set of books in various languages that constitutes the complement set of the item identified by focussing in (50a). But note that it is possible to create a dialogue in which the book in question may have additional properties along with being in English, provided that they are not in the same 'semantic dimension'.

\section{a. "János [EGY "ANGOL KöNYVET] kapott ajándékba. John an English book-ACC got as-present 'It was an English book that John got as a present.' b. Igen/\#Nem, János [EGY "UNALMAS ANGOL KöNYVET] Yes/No, John a boring English book-ACC kapott ajándékba. got as-present \\ 'Yes/\#No, it was a boring English book that John got as a pres- ent.'}

Just as (49b) is incapable of carrying VP-focus, so are (50a,b): they can only be understood as having constituent focus. But that is not at issue here; what we want to claim is that the case of (49b) resembles that of (50). According to (50a), John received an English book as a present (whether boring or not), as contrasted with a set of books in other languages (not excluding books exhibiting other properties, such as being boring, or thick, or green, etc.). Analogously, in (49b) the action of reading out Hamlet aloud is identified with respect to a complement set of actions of reading out Hamlet at some volume other than 'loud', not excluding actions of reading out Hamlet aloud in various other ways: quickly, slowly, clearly articulated, monotonously, etc., just as in (44a,b) and the related examples. That is why both manner adverbials and attributes are compatible with adjuncts along different 'dimensions', but neither can project focus onto the dominating phrase node: in the case of $(49 \mathrm{~b})$ it cannot be a set of actions at large with which 'reading out
Hamlet aloud' is contrasted, and in (50b) it cannot be a set of things in general with which 'an English book' is compared. And just as (50a) is not a possible answer to a question What happened (to John)?, so is (49b) not a possible reply to a similar information focus question What did Peter do at lunchtime yesterday?

The reason focussing a nonreferential adjunct like hangosan 'aloud' is compatible with focussing another nonreferential adjunct lies in the fact that the actions they characterize are themselves not incompatible, whereas when a referential argument or adjunct is focussed (and focus is not projected to the VP), the set denoted by the focussed expression differs from any other set - except for any one of its own subsets, which is the case in $(50 a, b)$.

These observations naturally carry over to other nonreferential adjuncts, including adverbials of reason, purpose, and so forth. This section has served to show that whenever a nonreferential adjunct is focussed it is not interpreted with respect to some set of independent 'adverbial denotations', but as part of the predicate, whose reference is available to constitute (subsets of) reference sets.

\section{Ontology and conclusion}

If we now take stock of what count as focussable expressions, we find VPs and clauses in addition to referential (i.e., specific or definite) noun phrases or DPs. Excluded are attributes, i.e., adjectival and numerical expressions in noun phrases, nonreferential noun phrases (or NPs, NumPs, etc.), nonreferential adverbials, verbs and other expressions of their kind. If we wish to generalize over the expressions that can undergo focussing, we might speculate that they closely correspond to the expressions that have reference (or denotation, Bedeutung) in terms of Frege's ontology.

The founding father of modern semantics, Gottlob Frege (1952), recognized two kinds of entities that linguistic expressions may denote (refer to, stand for, bedeuten): functions and objects. Corresponding to these two kinds, there are four types of linguistic expressions: (a) predicates, which are names of functions mapping objects to truth-values; (b) 'proper names' (or, in current terminology, referring expressions), (c) sentences and (d) subordinate clauses, which all denote objects, differing only in the kinds of objects they stand for: sentences denote two 
'special' objects, the True and the False, and are capable of having 'assertive force'; subordinate clauses denote their senses: the 'thought'; and 'proper names' denote all other kinds of objects, whether abstract or concrete. 5

If the function of focussing is identification with respect to a set of entities in the real or a possible world, the sets of entities thus invoked must have existence: there must be a set of countries, of which Italy is a member in example (3)/(14), there must be a set of actions possible at time $t$, of which reading out Hamlet in the garden is a member in (31), and there must be a set of real or 'true' states-of-affairs (i.e., Frege's 'the True'), of which one is that Yeltsin won the Russian elections in (35)-(36). But there is no set in the real or in a possible world that is comprised of various properties that books may have, such as boring and interesting, or English and German, etc., only sets of books of various properties, cf. (50). Just as there are no sets constructed of modes of ironing shirts, only sets of actions executed at time $t$, by agent $a$, including ironing some shirt quickly, ironing the same shirt beautifully, ironing it quickly and beautifully, etc., as in (44). In this Fregean world of functions and objects, focussing is thus interpreted with respect to (proper) subsets of sets of entities, i.e., the denotations of DPs, VPs or CPs/IPs.

When information focus and contrastive focus are compared, it transpires that the crucial ingredient in them is identification. However, while information focus makes no commitment as to what other entities constitute the relevant set for which the identification in question does or does not hold, contrastive focus must make such a commitment: outside of what is identified as the entity or entities for which the identification holds, there must be at least one other entity, whether thing, action, property, or state-of-affairs, to which the identification does not hold. This complement set may or may not have the same membership for speaker and hearer, but it must be nonempty. In other words, the exclusion by identification must be real.

Since information focus differs from contrastive focus only inasmuch as the former relies on the subset relation, while the latter relies on the proper subset relation, it follows that contrastive focus itself is a subset of information focus. In other words, all cases of contrastive focus are cases of information focus with the only difference that the contingency of a complement set in information focus turns into a necessity in the case of contrastive focus.
Notes

1. The research reported in this paper was supported in part by a joint grant from the Dutch Foundation for Scientific Research (NWO) and the Hungarian National Research Programs (OTKA, Grant No. N 37276) on "The syntax, semantics and phonology of the left periphery", as well as by the Collegium Budapest - Institute for Advanced Study by a fellowship. I am grateful to number of anonymous readers in addition to Michael Brody, Beáta Gyuris, Robert M. Harnish, Anikó Lipták, Márta Maleczki, Valéria Molnár, and Peter Sherwood for reading and commenting on various versions of this paper, and audiences at the Research Institute for Linguistics, Budapest, and the University of Lund, Sweden. All remaining errors are mine.

2. But note that É. Kiss (2002: 78) has 'proper subset' for 'subset', although she does not say why the change was called for.

3. This is practically the same as Jacobs' (1988: 113) claim: "Kontrastiv ist ein Fokus dann, wenn er im sprachlichen Kontext explicit irgendwelchen Fokusalternativen gegenüberstellt wird".

4. The corresponding wh-question is also unintelligible, except if it is a genuinely silly question or addressed to a simpleton with a characteristic rising intonation, instead of the normal falling one.

(i) $M i$ sütött $k i$ a felhók közül?

what shone PV the clouds behind

'What shines through the clouds?'

Misi Brody (personal communication) noted that such sentences are dependent on our knowledge of the world (since there can be worlds with more than one sun), and their semantic properties do not follow from the meanings of the words in them. I do not see the consequences to be fatal: as argued here, focu has to do with (sets of) denotations, i.e. entities in the real or possible worlds, therefore the judgements passed on these sentences are dependent on what is the case. (Note that unlike English and several other languages, the moon an the stars do not süt in Hungarian, the reason being that süt involves the production of heat, unlike shine, which is equivalent to 'emitting light'.)

5. This is not the proper place to review either Frege's work or the literature on it. Note that the views adopted here are somewhat closer to Klemke's (1968 position on Frege's ontology than to Dummett's $(1973,1981)$. 


\section{References}

Ambar, Manuela

1999 Aspects of the syntax of focus in Portuguese. In Georges Rebuschi, and Laurie Tuller (eds.), 23-55.

Bayer, Joseph

1999 Bound focus or how can association with focus be achieved without going semantically astray? In Georges Rebuschi, and Laurie Tuller, 55-82.

Bolinger, Dwight

1961 Contrastive accent and contrastive stress. Language 37: 83-96.

Brody, Michael

1990 Remarks on the order of elements in the Hungarian focus field. In Approaches to Hungarian Vol. 3, István Kenesei (ed.), 95-122. Szeged: JATE.

Choe, Hyon Sook

1995 Focus and topic movement in Korean and licensing. In Discourse Configurational Languages, Katalin É. Kiss (ed.), 269-334. Oxford: Oxford University Press.

Chomsky, Noam

1971 Deep structure, surface structure and semantic interpretation. In Semantics: An Interdisciplinary Reader, Danny D. Steinberg, and Leon A. Jakobovits (eds.), 183-216. Cambridge: Cambridge University Press.

1976 Conditions on rules of grammar. Linguistic Analysis 2: 303-351.

1977 On wh-movement. In Formal Syntax, Peter W. Culicover, Thomas Wasow, and Adrian Akmajian (eds.), 71-132. New York: Academic Press.

Dummett, Michael

1973 Frege: Philosophy of Language. London: Duckworth.

1981 The Interpretation of Frege's Philosophy. Cambridge: Harvard University Press.

\section{É. Kiss, Katalin}

1992 Az egyszerú mondat szerkezete [The structure of the simple sen tence]. In Strukturális magyar nyelvtan I: Mondattan, Ferenc Kiefer (ed.), 79-178. Budapest: Akadémiai Kiadó.

1998 Identification focus versus information focus. Language 74: 245-273. 2002 The Syntax of Hungarian. Cambridge: Cambridge University Press.

Frege, Gottlob

1952 Translations from the Philosophical Writings of Gottlob Frege (ed. by Peter T. Geach and Max Black). Oxford: Blackwell.
Guéron, Jaqueline

1980 On the syntax and semantics of PP extraposition. Linguistic Inquiry 11: 637-678.

Gundel, Jeanette K.

1999 On different kinds of focus. In Focus: Linguistic, Cognitive and Computational Perspectives, Peter Bosch, and Rob van der Sand (eds.). Cambridge: Cambridge University Press.

Gussenhoven, Carlos

1984 On the Grammar and Semantics of Sentence Accents. Dordrecht: Foris.

Hetland, Jorunn, and Valéria Molnár (eds.)

2003 Structures of Focus and Grammatical Relations. Tübingen: Niemeyer.

Hetzron, Robert

1975 The presentative movement or why the ideal word order is V.S.O.P. In Word Order and Word Order Change, Charles N. Li, and Sandra Thompson (eds.), 346-388. Austin: University of Texas Press.

Höhle, Tilmann M.

1988 Verum focus. Sprache und Pragmatik 5: 1-7. Lund.

Jackendoff, Ray

1972 Semantic Interpretation in Generative Grammar. Cambridge, Massachusetts: MIT Press.

Jacobs, Joachim

1988 Fokus-Hintergrund-Gliederung und Grammatik. In Intonationsforschungen, Hans Altmann (ed.), 89-134. Tübingen: Niemeyer.

Kenesei, István

1984 On what really figures in a nonconfigurational language. Groninge Arbeiten zur germanistischen Linguistik 24: 28-54.

1986 On the logic of word order in Hungarian. In Topic, Focus and Confi gurationality, Werner Abraham, and Sjaak de Mey (eds.), 143-159 Amsterdam: John Benjamins.

1994 Subordinate clauses. In The Syntactic Structure of Hungarian Ferenc Kiefer, and Katalin É. Kiss (eds.), 275-374. San Diego: Aca. demic Press.

1998 Adjuncts and arguments in VP-focus in Hungarian. Acta Linguisticc Hungarica 45: 61-88.

Kenesei, István, and Irene Vogel

1998 A fókusz fonológiai szerkezete [The phonological structure of focus] In Általános Nyelvészeti Tanulmányok 19, Mihály Péter (ed.), 79 119.

Klemke, E. D. (ed.)

1968 Essays on Frege. Urbana: University of Illinois Press. 
Molnár, Valéria, and Marja Järventausta.

2003 Discourse configurationality in Finnish and Hungarian. In Jorunn Hetland, and Valéria Molnár, 111-148.

Rebuschi, Georges, and Laurie Tuller (eds.)

1999 The Grammar of Focus. Amsterdam: Benjamins.

Roberts, Craige

1998 Focus, the flow of information, and universal grammar. In The $\mathrm{Li}$ mits of Syntax, Peter Culicover, and Louise McNally (eds.), 109-160. San Diego: Academic Press.

Rochemont, Michael S.

1986 Focus in Generative Grammar. Amsterdam: John Benjamins.

Rooth, Mats

1985 Association with Focus. University of Massachusetts, Amherst: Unpublished Ph. D. diss.

Russell, Bertrand

1905 On denoting. Mind 14: 479-493.

Schmerling, Susan

1976 Aspects of English Sentence Stress. Austin, Texas: University of Texas Press.

Selkirk, Elizabeth O.

1984 Phonology and Syntax. Cambridge, Massachusetts: MIT Press.

Szabolcsi, Anna

1981a Compositionality in focus. Folia Linguistica 15: 141-161.

1981b The semantics of topic-focus articulation. In Formal Methods in the Study of Language, MC Tract 126, Jeroen Groenendijk, Theo Janssen, and Martin Stokhof (eds.), 513-540. Amsterdam.

1994 All quantifiers are not equal: The case of focus. Acta Linguistica Hungarica 42: 171-187.

Szabolcsi, Anna (ed.)

1997 Ways of Scope Taking. Dordrecht: Kluwer.

Taglicht, Joseph

1984 Message and Emphasis: On Focus and Scope in English. London: Longman.

Vogel, Irene, and István Kenesei

1987 The interface between phonology and other components of grammar. Phonology 4: 243-263.

1990 Syntax and semantics in phonology. In: The Phonology-Syntax Connection, Draga Zec, and Sharon Inkelas (eds.), 339-363. Chicago: University of Chicago Press.

Zubizarreta, Maria Luisa

1998 Prosody, Focus, and Word Order. Cambridge, Massachusetts: MIT Press.

\section{Focussing as predication}

\author{
Katalin É. Kiss
}

\section{Abstract}

The paper argues for a new approach to structural focus, which eliminates the problems raised by the standard $F$ (ocus)P theory. The starting point of the analysis is the claim that the Hungarian sentence contains a PredP projection above VP, harboring the verbal particle functioning as a resultative, terminative, or locative secondary predicate. It is claimed that the focus constituent, which appears preverbally in the Hungarian sentence, is an alternative filler of the Spec,PredP position. The 'exhaustive listing', or 'exhaustive identification' interpretation associated with the focus arises when the constituent raised to Spec,PredP is a definite or a specific indefinite noun phrase, which receives a specificational reading in predicate position. In the theory of Higgins (1973) and S. Huber (2000), a specificational predicate serves to referentially characterize the set denoted by the subject of predication, in other words, to exhaustively list its referential content. The Spec,PredP position is also the prosodically most prominent position of the sentence, hence its filler - whether a verbal particle or a specificational predicate - is interpreted as the information focus.

\section{Introduction}

This paper proposes a new approach to structural focus expressing exhaustive identification. After showing that the current theory of structural focus, originating in Brody $(1990,1995)$, raises various theoretical and empirical problems, it presents an alternative account of focus which can derive a wider range of facts in a more economical way, by a division of labor among existing, independently motivated syntactic, semantic and phonological means of grammar. It will be argued that the 